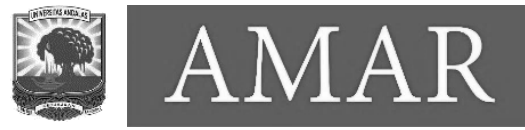

AMAR (Andalas Management Review)

Vol. 3, No. 2 (2019) Halaman 54-75

The Management Institute, Faculty of Economics, Universitas Andalas

ISSN (Print) 2476-9282 | ISSN (Online) 2548-155X

\title{
Business Development Strategy of Expedition Companies: A Case Study
}

\author{
Prima Fithria, Hilma Raimona Zadryb , Debi Ansulyc \\ $a, b, c$ Industrial Engineering Department, Engineering Faculty, Universitas Andalas
}

\begin{abstract}
The development of information and communication technology which is rapidly increasing now causes changes in people's behavior in shopping. This is supported by the increasing number of online shopping or e-commerce businesses in the community. PT Pos Indonesia as a business entity engaged in sending letters and packages also has considerable opportunities in this business. However, the strength of PT Pos Indonesia at this time cannot be said to be good, because, based on the results of a survey conducted on 30 samples of people and students in the city of Padang showed that only about 7\% of people chose PT Pos Indonesia as a courier for shipping goods. This research was conducted to design the right business strategy for PT Pos Indonesia to compete in the package or goods delivery business using Strengths Weaknesses Opportunities and Threats (SWOT) analysis. From the results of the strategic plan made, it can be concluded that PT Pos Indonesia Padang is in a good internal and external environment. However, PT Pos Indonesia's position compared to its competitors is weak. Based on Quantitative Strategic Planning Matrix (QSPM), the proposed strategy given to PT Pos Indonesia Padang in such company conditions is an intensive strategy.
\end{abstract}

Keyword: PT. Pos Indonesia, SWOT Analysis, QSPM, Shipping Goods

\section{INTRODUCTION}

The rapid development of information and communication technology today has a negative and positive impact on people's behavior, one of them is changing the behavior of people in shopping (Madni, 2014; Wamuyu, 2015; Doni and Faqih, 2017). With the development of this information technology, people prefer to shop via online compared to shopping on the spot (Papagiannidis et al., 2017; Schmid and Axhausen, 2017; Saxena, 2019). With online shopping, buyers only need to connect to the Internet, to be able to choose the desired item. After making a transaction between the seller and the buyer, the seller will deliver the goods ordered by the buyer using the courier service. This behaviour becomes a trend that we often meet in Indonesian 
society today. In this situation, courier service is very important role in the business smooth, so opening up big opportunities for freight services expanding their market.

Minister of Communication and Information of Indonesia mentioned that $7 \%$ of internet users in Indonesia have been shopping online and this number will continue to increase with the development of communication technology. Data from the ICD Research Institute predicts that the e-commerce market in Indonesia will grow 42\% from 2012-2015. Data owned by Master Card World Wide showed that there was an increase in e-commerce sales in Indonesia from 2013 of $U$ $\$ 1.79$ billion to U $\$ 2.60$ billion in 2014 (Edisi, 2014).

An increasingly lively online business in the country, a blessing for the perpetrators of the expedition services. Various types of expedition services are increasingly active offering a variety of sophistication and speed of distribution system to lure cyber consumers who always want speed and timeliness. With the increasing income of online business spending will automatically boost the income delivery service. This is because, as small as any item purchased via online definitely needs delivery service so that the goods can reach the consumer's hands quickly and safely. That fact has become a blessing for the entrepreneurs of logistics, distribution, and Expedition (Direktorat Jenderal Perdagangan Dalam Negeri, 2012). PT Pos Indonesia As one of the business entities engaged in the delivery of letters and packages also has a considerable opportunity to face the behavior of Indonesian society like this. This is because online businesses desperately need delivery services to deliver goods ordered by consumers.

Preliminary survey was conducted in April 2014 in Padang City against 30 community and students who often use courier delivery of goods. Based on the survey, it is known that PT Pos Indonesia as state-owned enterprises does not master the market monopolies. PT Pos Indonesia must compete with private owned enterprises that have a substantial market share. Therefore, to be able to compete with its stronger competitors, PT Pos Indonesia must have a strong strategy to be able to penetrate the market. But the strength of PT Pos Indonesia is not currently well-said, because from 2003 to 2008 the financial performance of PT Pos Indonesia is always minus (Sinaga, 2012). The results of the survey also showed that nearly 43\% of people chose to use JNE as courier shippers of their goods or packages. The second order was ruled by TIKI as much as $27 \%$, followed by another delivery service of $23 \%$, and PT Pos Indonesia only 
7\%. Figure 1.1 shows that most people trust JNE and TIKI as courier delivery of goods compared to PT Pos Indonesia.

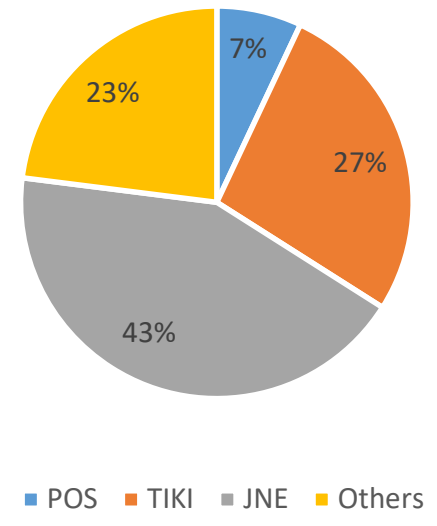

Figure 1. Delivery service frequently used by people in Padang City

The survey results also show that the reason people prefer private owned enterprises than PT Pos Indonesia to send goods or packages are the speed of delivery as well as cheaper prices. Private owned enterprises such as JNE and TIKI offer a lot of options delivery of goods, even goods can be arrived in the period of one day only. This is what causes the community prefer JNE or TIKI. In addition, the level of public confidence in PT Pos is still low. Some reasons are expressed by the public about the distrust of PT Pos Indonesia such as damaged goods, not fast until, wrong shipping, and others.

PT Pos Indonesia has many branch offices scattered throughout Indonesia. In this research, the strategy planning to be done is at PT Pos Indonesia Padang located at Jl. Aziz Chan No. 7 Padang. The checkpoint office is the Centre for branch offices in the area of Padang, so the branch offices coordinate with the checkpoint's post office. Business strategy planning in the office of PT Pos Indonesia Padang was conducted by the Inspector Office itself adapted to the environment of its marketing area. The strategy that is set by PT Pos Indonesia Padang also applies to the branch office in the city of Padang.

Therefore, PT Pos Indonesia Padang, especially the parcel delivery package, must have the right development strategy plan in order to compete with its competitors. To be able to survive the current condition, PT Pos Indonesia Padang must be observant in finding the right strategy so that the company can increase the market share more and more day. If PT Pos Indonesia does not have the right strategy plan, the competitor company will easily turn off the 
business delivery of PT Pos Indonesia Padang. This study aims to determine the current position of PT Pos Indonesia Padang as a package delivery business entity in Indonesia and develop the business strategy that must be carried out by PT Pos Indonesia Padang in the field of package delivery in order to compete with its competitors.

SWOT analysis is the first step in management strategy to identify what factors affect the company both internal and external (Lukito, Lianto and Surjani, 2013). SWOT analysis is carried out to describe the external factors which include Opportunities and Threats of the company as well as internal factors which include the Strengths and Weaknesses. From the results of literature studies that have been conducted on several previous studies regarding business strategy planning in companies, it is known that the method used is a SWOT analysis. Here are some studies using the SWOT method:

a. Business Strategy Designation at PT Coronet Crown (Lukito, Lianto and Surjani, 2013). In this research a strategic planning is carried out on one of the products produced by PT Coronet Crown. The method used is the SWOT analysis and porter analysis. The input stage is carried out using a SWOT matrix, IFE matrix, and EFE. The matching stage uses the IE matrix, CPM matrix, and the Big Strategy matrix. The Decision Stage uses the QSPM method. In this study no study was conducted on the financial aspects.

b. Designing Semen Padang Hospital's Strategic Branch Development (Amaly, 2013). In this study, researchers also used a SWOT analysis. The input stage is carried out using the IFE matrix and EFE matrix. The matching stage uses IE matrix and SWOT matrix. While the decision stage uses the AHP method. In this study no study was conducted on the financial aspects.

c. Strategic Planning for the Municipal Water Supply Company in Padang (Rozelin, 2008). In this study, researchers conducted corporate strategy planning using SWOT analysis. The input stage is done by the IFE and EFE matrices. Stage matching with SWOT matrix, Space matrix, IE matrix, and large strategy matrix. And for the decision stage using the QSPM method. In this study a study was conducted using the financial aspect, therefore this study used the Space matrix at the matching stage.

Based on the literature study that has been done, the method used in this study is the SWOT analysis, where the input stage is carried out using the IFE matrix and EFE matrix. The 
matching stage uses the CPM matrix. It aims to determine the position of the Padang Indonesia Examiner Pos compared to its competitors, TIKI and JNE. The choice of TIKI and JNE is because these two competitors have a fairly large market share compared to other shipping services. It also uses the IE matrix to determine the position of PT Pos Indonesia Padang from the results of evaluations of external and internal factors that have been carried out. Finally, using the Big Strategy matrix to determine the company's position based on competitive position and market growth. This competitive position can be known from the results of the CPM matrix that has been done before. The decision stage is carried out using the QSPM method, because the QSPM method is carried out by direct assessment by PT Pos Indonesia, especially the package delivery section. So the value obtained is expected to be more accurate.

\section{METHODS}

\subsection{SWOT Analysis}

The following is the SWOT analysis of PT Pos Indonesia Padang:

a. Legal Aspects

This aspect is related to the law governing Pos Indonesia. The indicator for this aspect is Law No. 38 of 2009 governing Pos Indonesia.

b. Technological Aspects

This aspect is related to technology that supports the development of the current shipping business, such as information technology that makes it easy for consumers to access information about shipping goods. The indicator used in this aspect is the technology used in distribution and service.

\section{c. Socio-Cultural Aspects}

This aspect is related to the culture of the people who increasingly use courier services and data on the level of public education, because internet usage is influenced by the level of public education. Indicators for this aspect are changes in people's behavior in shopping.

d. Economic aspects

This aspect relates to the economy of the people of the city of Padang in terms of the value of national inflation and the growth of the Gross Regional Domestic Product (GRDP) of the city of Padang and the growth of online businesses. The indicator used in this aspect is economic growth. 


\section{e. Competitor Aspects}

Analysis of the strength of competition between shipping services in Indonesia, such as the number of private shipping companies in the city of Padang. Indicators of this aspect are seen from existing competitors.

f. Customer Aspect

This aspect is based on the expedition service customers themselves, the population growth of the city of Padang and cooperation with other parties. Indicators of this aspect are customers of PT Pos Indonesia Padang.

g. Weather Aspects

This aspect is based on weather conditions in an area. Weather aspects that affect the process of distributing package delivery by shipping companies such as floods and storms.

For PT Pos Indonesia Padang's internal environment, the aspects used in this study is adjusted to the internal environment conditions of PT Pos Indonesia Padang as a company engaged in services. The aspects used are:

a. Human Resources Aspects

This aspect explains the state of the existing human resources at PT Pos Indonesia Padang, particularly in the section on shipping goods and packages. Indicators for this aspect include the availability of human resources, work motivation, human resource skills, and the age of human resources.

b. Service Aspects

This aspect explains the services provided by PT Pos Indonesia Padang to customers. PT Pos Indonesia Padang is a company engaged in services, so service aspects are very important as aspects that are assessed. Indicators of this aspect are the availability of operational equipment, facilities or supporting facilities, the right service, the right service process, guaranteed delivery of goods, and the ease and friendliness of employees.

c. Marketing Aspects

Marketing aspects are divided into price, place, promotion, customers (people), physical evidence, and the process.

\subsection{Strategy Formulation}


The strategy formulation is carried out with three stages namely the input stage, the matching stage, and the decision stage.

a. The Input Stage

At this stage the formulation framework consists of the External Factor Evaluation (EFE), the Internal Factor Evaluation (IFE), and Competitive Profile Matrix (CPM) matrix.

1.) External Factor Matrix (EFE)

This matrix is used to see the value of the company from external factors consisting of legal, economic, technological, socio-cultural, competitor and customer aspects. Each of these aspects is described in more detail in the form of indicators which are weighted by PT Pos Indonesia Padang.

2.) Internal Factor Matrix (IFE)

The IFE matrix is carried out to determine the weight of PT Pos Indonesia Padang's internal strengths, which includes weaknesses and strengths that they have.

3.) Competitive Profile Matrix (CPM)

CPM matrix is done to see the condition of the company compared to competitors. Competing companies that can be used as a comparison with PT Pos Indonesia Padang are TIKI and JNE. This is because the position of TIKI and JNE has a very strong influence on the package delivery business in Indonesia.

b. The Matching Stage

At the matching stage a logical alternative strategy can be generated by taking into account external and internal factors that have been formulated at the input stage.

\section{1.) Internal External Matrix (IE)}

IE Matrix is conducted to determine the company's position based on internal and external factors of the company. These factors are predetermined from the EFE and IFE matrices in the previous step. To find out the position of the company with this matrix, it is enough to use the weight scores that have been obtained from the EFE and IFE matrices at the previous input stage. In this matrix there are nine quadrants with each quadrant having his strategy. Determination of the position quadrant of PT Pos Indonesia Padang by entering the IFE weight score on the $\mathrm{x}$ axis and EFE weight score on the $\mathrm{y}$ axis. 


\section{2.) SWOT Matrix}

The next step is to create a SWOT matrix by grouping each of the strengths, weaknesses, opportunities and threats that exist at PT Pos Indonesia Padang. After that, formulating an alternative strategy from the combination of each factor that has been identified, namely the SO (Strength-Opportunities) strategy, the WO (WeaknessOpportunities) strategy, the ST (Strength-Threats) strategy, and the WT (WeaknessThreats) strategy.

\section{3.) Major Strategy Matrix}

This Major Strategy Matrix is determined based on two dimensions, namely competitive position and market growth. The competitive position of PT Pos Indonesia Padang can be known based on the CPM Matrix that was made at the previous input stage. While market growth can be known based on the current situation. This information can be obtained based on interviews or other supporting data (the rate of growth of the package delivery service business). In this matrix there are four quadrants

that will determine the strategy that can be done by the company based on these two dimensions.

c. The Decision Stage

The decision stage is carried out using QSPM. At this stage, it will be known what strategies are right for the company as a competitive strategy in dealing with competitors. At this stage the decision was made with the help of PT Pos Indonesia Padang as a party who understood the company's condition.

\section{RESULTS AND DISCUSSIONS}

\subsection{Strategy Formulation}

a. The Input Stage

1.) External Factor Matrix (EFE)

The EFE matrix shows the condition of PT Pos Indonesia Padang's external environment. The preparation of the EFE matrix identifies external factors in the form of opportunities and threats faced by PT Pos Indonesia Padang. The determination of weights and rankings was carried out by four respondents from PT Pos Indonesia Padang, 
which consisted of Branch Managers of PT Pos Indonesia Padang, Marketing Managers, SLPK Managers, and Assistant Post Package Managers.

Table 1

PT Pos Indonesia Padang EFE Matrix

\begin{tabular}{|c|c|c|c|c|}
\hline No. & Factors & Weight & Rank & $\begin{array}{l}\text { Neighted } \\
\text { Score }\end{array}$ \\
\hline \multicolumn{5}{|c|}{ Opportunity } \\
\hline 1 & $\begin{array}{l}\text { Availability of information technology for customers } \\
\text { (website) }\end{array}$ & 0,10 & 3,25 & 0,33 \\
\hline 2 & $\begin{array}{l}\text { The rate of economic growth of the people of the city } \\
\text { of Padang }\end{array}$ & 0,10 & 3,00 & 0,29 \\
\hline 3 & Online business growth rates in Indonesia & 0,08 & 3,25 & 0,28 \\
\hline 4 & $\begin{array}{l}\text { Community culture towards the use of courier } \\
\text { services }\end{array}$ & 0,08 & 2,50 & 0,20 \\
\hline 5 & $\begin{array}{l}\text { The level of education of the people of the city of } \\
\text { Padang }\end{array}$ & 0,06 & 3,00 & 0,17 \\
\hline 6 & Customer loyalty to PT Pos Indonesia & 0,08 & 3,50 & 0,30 \\
\hline 7 & Population growth in the city of Padang & 0,08 & 3,00 & 0,25 \\
\hline 8 & $\begin{array}{l}\text { Government projects that require distribution of goods } \\
\text { (elections) }\end{array}$ & 0,11 & 4,00 & 0,45 \\
\hline \multicolumn{4}{|c|}{ Weighted Score of Oportunity } & 2,264 \\
\hline \multicolumn{5}{|c|}{ Threath } \\
\hline 9 & Establishment of a private shipping company & 0,107 & 2,5 & 0,268 \\
\hline 10 & Public image of PT Pos Indonesia & 0,096 & 2,75 & 0,264 \\
\hline 11 & $\begin{array}{l}\text { The influence of government policy opens up } \\
\text { opportunities } \\
\text { freight forwarding business for the private sector, } \\
\text { BUMD, and cooperatives }\end{array}$ & 0,096 & 2,75 & 0,264 \\
\hline \multicolumn{4}{|c|}{ Weighted Score of Threat } & 0,797 \\
\hline & TOTAL & 1 & & 3,061 \\
\hline
\end{tabular}

Table 1 shows that the total score weighting of PT Pos Indonesia Padang's EFE matrix is 3.061. Meanwhile, according to (David, 2009), the average value for the total weight score on the EFE matrix is 2.5. Thus, the total weighting score of PT Pos Indonesia Padang is above the average. This value indicates that PT Pos Indonesia Padang on average is able to take advantage of external opportunities and avoid existing threats. Furthermore, the EFE matrix calculation also shows that the scores for opportunities and threats are 2.264 and 0.796 , respectively. The value of the opportunity score that is greater than the threat score indicates that the company gives a higher response to the opportunity factor than its response to the threat factor. 
The biggest opportunity faced by PT Pos Indonesia Padang is the existence of government projects such as elections that require distribution with a weight of 0.113 and a ranking value of 4 . While for the greatest threat faced by PT Pos Indonesia Padang is the public image of PT Pos Indonesia and the influence of government policies opens a business opportunity for shipping goods to BUMD, private sector, and cooperatives with a weight of 0.096 . The response of PT Pos Indonesia Padang to the threat factor is still low at 2.750 .

2.) Internal Factor Matrix (IFE)

The IFE matrix is carried out after the identification of internal factors of PT Pos Indonesia Padang, which consists of strengths and weaknesses owned by the company. The preparation of the IFE matrix is done by giving the value of the weights and ratings determined by the respondents. Respondents consisted of PT Pos Indonesia Padang which consisted of Branch Heads, Marketing Managers, SLPK Managers, and Assistant Post Package Managers of PT Pos Indonesia Padang.

Table 2

PT Pos Indonesia Padang's IFE Matrix

\begin{tabular}{llccc}
\hline No. & \multicolumn{1}{c}{ Factors } & \multicolumn{2}{c}{ Weighted } \\
\multicolumn{2}{l}{ Strength } & & & \\
\hline 1 & Number of marketing staff & 0,036 & 3,25 & 0,116 \\
\hline 2 & Number of warehouse staff & 0,031 & 3,25 & 0,102 \\
\hline & The level of work motivation for employees and & & & \\
3 & experts & 0,036 & 3,25 & 0,116 \\
\hline 4 & Providing incentives for employees & 0,036 & 3,25 & 0,116 \\
\hline 5 & Work skills of all employees & 0,034 & 3,25 & 0,109 \\
\hline 6 & Relative age of employees (productive age) & 0,036 & 3 & 0,107 \\
\hline 7 & The number of goods shipping service counters & 0,038 & 4 & 0,151 \\
\hline 8 & Amount and condition of shipping transportation & 0,038 & 3,5 & 0,132 \\
\hline 9 & Parking facilities available & 0,025 & 3,5 & 0,088 \\
\hline 10 & The state of building construction & 0,034 & 3,25 & 0,109 \\
\hline 11 & Building aesthetics & 0,031 & 3,5 & 0,110 \\
\hline 12 & Skill of employee service at counters to consumers & 0,042 & 3,25 & 0,136 \\
\hline 13 & Skill of employee service to consumer complaints & 0,042 & 3,25 & 0,136 \\
\hline 14 & Speed of response of employee services at counters & 0,042 & 3 & 0,126 \\
\hline & Speed of response to customer service complaints by & & & \\
15 & consumers & 0,042 & 3,25 & 0,136 \\
\hline
\end{tabular}




\begin{tabular}{|c|c|c|c|c|}
\hline No. & Factors & Weight & Rank & $\begin{array}{l}\text { Weighted } \\
\text { Score }\end{array}$ \\
\hline 16 & Able to track the position of goods & 0,042 & 4 & 0,168 \\
\hline 17 & Availability of guaranteed replacement of lost items & 0,042 & 4 & 0,168 \\
\hline 18 & Friendliness of security services & 0,040 & 3 & 0,119 \\
\hline 19 & Ease of filing complaints by consumers & 0,042 & 3,25 & 0,136 \\
\hline 20 & Ease of information services & 0,040 & 3,25 & 0,129 \\
\hline 21 & $\begin{array}{l}\text { The affordability of the location of PT Pos Indonesia } \\
\text { by consumers }\end{array}$ & 0,038 & 3,75 & 0,142 \\
\hline 22 & Security of PT Pos Indonesia & 0,038 & 3,5 & 0,132 \\
\hline 23 & Goods shipping costs & 0,040 & 3,75 & 0,149 \\
\hline \multicolumn{2}{|r|}{ Total Weighted Score of Strength } & & & 2,934 \\
\hline \multicolumn{5}{|c|}{ Weakness } \\
\hline 24 & Promotion / advertisement level & 0,029 & 1,75 & 0,051 \\
\hline 25 & Number of senders (couriers) & 0,025 & 2 & 0,050 \\
\hline 26 & Skill of security services & 0,023 & 2 & 0,046 \\
\hline 27 & Information service skills by employees & 0,029 & 1,75 & 0,051 \\
\hline 28 & $\begin{array}{l}\text { Friendliness of employee services at the ticket } \\
\text { window }\end{array}$ & 0,031 & 1,75 & 0,055 \\
\hline \multirow{2}{*}{\multicolumn{2}{|c|}{$\begin{array}{l}\text { Total Weighted Score of Weaknesss } \\
\text { TOTAL }\end{array}$}} & & & 0,254 \\
\hline & & 1 & & 3,188 \\
\hline
\end{tabular}

Weight values are given based on the influence of these factors on the development of PT Pos Indonesia Padang. This value is used as an input for the IFE matrix to find the total weight score value multiplied by the ranking value. In the PT Pos Indonesia Padang IFE matrix, the total weight score is 3.188 . This total weighting score is above the average (2.5), so it can be said that the situation of PT Pos Indonesia Padang is able to utilize its strengths and is able to overcome existing weaknesses.

The greatest strength possessed by PT Pos Indonesia Padang is the number of goods shipping service counters, capable of tracking the position of goods, and the availability of collateral lost goods with a rating value of 4 . While for the greatest weakness possessed by PT Pos Indonesia Padang is the level of promotion, information service skills by employees, and employee service hospitality skyrocketed with a rating of 1.75.

3.) Competitive Profile Matrix (CPM)

This Competitive Profile Matrix (CPM) is used to determine the company's position compared to its competitors. PT Pos Indonesia Padang's competitors are based on market share owned by its competitors. According to interviews with PT Pos Indonesia 
Padang's Marketing Manager, PT Pos Indonesia Padang's competitors are JNE and TIKI. Data collection on the CPM was carried out by interviews with four respondents from PT Pos Indnesia Padang (Head of Pos Indonesia Padang Branch, Marketing Manager, SLPK Manager, and Assistant Package Manager Post) and JNE (Marketing Manager) and TIKI (Marketing Manager).

\section{Table 3}

CPM of PT Pos Indonesia Padang

\begin{tabular}{|c|c|c|c|c|c|c|c|c|}
\hline \multirow[t]{2}{*}{ No. } & \multirow[t]{2}{*}{ Important Sucsess Factors } & \multirow[t]{2}{*}{ Weight } & \multicolumn{2}{|c|}{$\begin{array}{c}\text { PT Pos } \\
\text { Indonesia } \\
\end{array}$} & \multicolumn{2}{|c|}{ JNE } & \multicolumn{2}{|c|}{ TIKI } \\
\hline & & & Rank & Score & Rank & Score & Rank & Score \\
\hline 1 & $\begin{array}{l}\text { Ease of contacting and } \\
\text { communicating with } \\
\text { companies }\end{array}$ & 0,059 & 3,25 & 0,190 & 4 & 0,234 & 3 & 0,176 \\
\hline 2 & $\begin{array}{l}\text { Company speed in } \\
\text { responding to customers }\end{array}$ & 0,074 & 3 & 0,223 & 4 & 0,297 & 3 & 0,223 \\
\hline 3 & $\begin{array}{l}\text { Promotion conducted by the } \\
\text { company }\end{array}$ & 0,078 & 2,25 & 0,176 & 4 & 0,313 & 3 & 0,234 \\
\hline 4 & $\begin{array}{l}\text { Punctual delivery of goods } \\
\text { to the destination }\end{array}$ & 0,078 & 3,25 & 0,254 & 4 & 0,313 & 4 & 0,313 \\
\hline 5 & $\begin{array}{l}\text { Knowledge and technical } \\
\text { mastery of the company in } \\
\text { conducting } \\
\text { shipping and payment } \\
\text { process }\end{array}$ & 0,070 & 3,250 & 0,229 & 4 & 0,281 & 3 & 0,211 \\
\hline 6 & $\begin{array}{l}\text { Responsive employee } \\
\text { services for customers }\end{array}$ & 0,074 & 3,25 & 0,241 & 4 & 0,297 & 3 & 0,223 \\
\hline 7 & $\begin{array}{l}\text { Friendliness and politeness } \\
\text { of employees to customers }\end{array}$ & 0,066 & 3,25 & 0,216 & 4 & 0,266 & 4 & 0,266 \\
\hline 8 & $\begin{array}{l}\text { The vehicle provided is still } \\
\text { feasible to operate }\end{array}$ & 0,063 & 3,25 & 0,203 & 4 & 0,250 & 4 & 0,250 \\
\hline 9 & $\begin{array}{l}\text { Safety of goods during the } \\
\text { trip to their destination }\end{array}$ & 0,078 & 3,75 & 0,293 & 4 & 0,313 & 4 & 0,313 \\
\hline 10 & Price competitiveness & 0,078 & 3,5 & 0,273 & 2 & 0,156 & 2 & 0,156 \\
\hline 11 & Market share & 0,070 & 2,25 & 0,158 & 4 & 0,281 & 3 & 0,211 \\
\hline 12 & Consumer loyalty & 0,063 & 2,25 & 0,141 & 4 & 0,250 & 3 & 0,188 \\
\hline 13 & Ease of checking items & 0,078 & 3 & 0,234 & 3 & 0,234 & 3 & 0,234 \\
\hline 14 & $\begin{array}{l}\text { Flexibility in the shape and } \\
\text { size of the goods sent }\end{array}$ & 0,070 & 3,25 & 0,229 & 3 & 0,211 & 3 & 0,211 \\
\hline & TOTAL SCORE & 0 & & 3,060 & & 3,695 & & 3,207 \\
\hline
\end{tabular}

According to the results obtained about CPM, it can be concluded that the position of PT Pos Indonesia Padang is weak. This can be seen from the total value of PT Pos 
Indonesia which is 3.060 lower than its competitors, namely JNE and TIKI which have a total value of 3.695 and 3.207, respectively. Based on the results obtained, it appears that the CPM value of PT Pos Indonesia Padang is quite different compared to its competitors. Therefore, PT Pos Indonesia Padang should improve its position so that it can be superior to JNE and TIKI.

b. The Matching Stage

1.) Internal External Matrix (IE)

IE matrix is a combination of information obtained at the input stage, namely the EFE matrix and the IFE matrix.

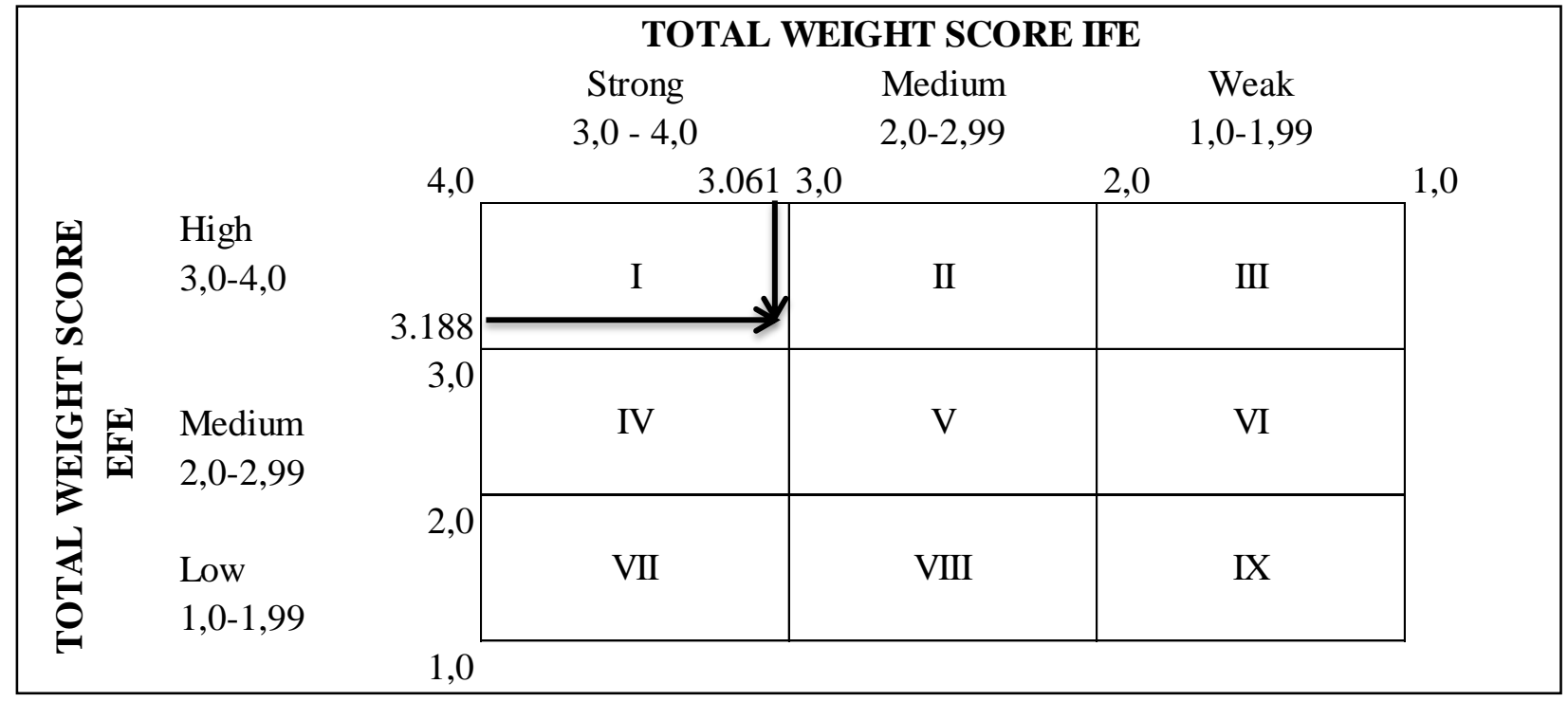

Figure 2. IE Matrix

Based on the total score, it is shown that the position of PT Pos Indonesia Padang is in cell I (Figure 2). In cell I strategies that can be used is to grow and build. Alternative strategies that can be carried out for company conditions like this are integrated strategies such as backward-forward or horizontal integration and intensive strategies such as market penetration, product development, and market development. Market penetration is an effort to increase sales of old products in the old market by strengthening the promotion aspects with more effective and varied advertisements according to the target market. Furthermore, market development is a strategy where companies seek growth by marketing existing products to new markets. Product development is an effort to increase sales by improving or modifying existing products and services.

2.) SWOT Matrix 
Based on the opportunities, threats, strengths and weaknesses that have been obtained from the analysis of PT Pos Indonesia Padang's external and internal environment (Table 4), an alternative strategy is formulated using SWOT (Table 5).

Table 4

SWOT Matrix

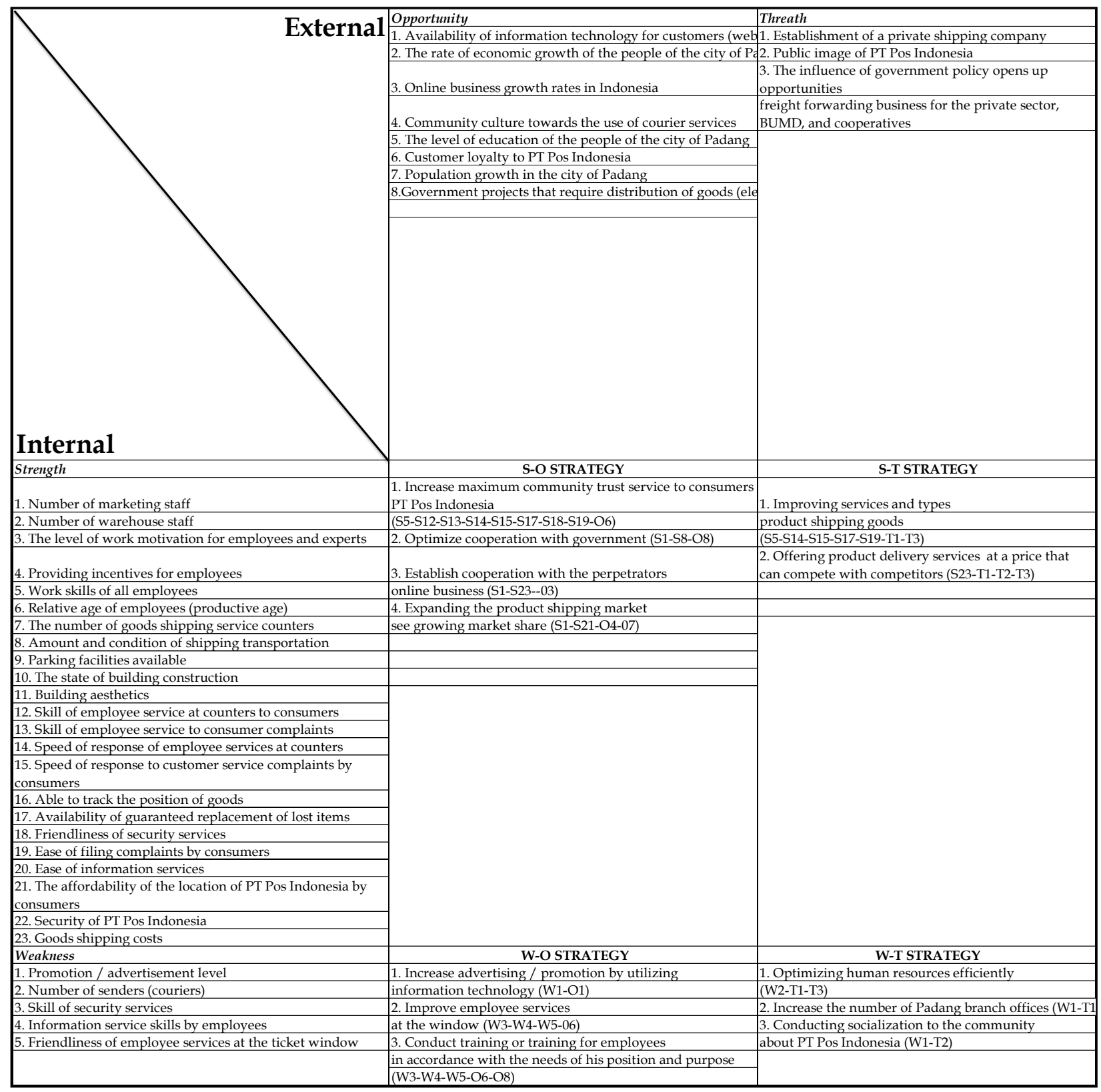


Table 5

Alternative SWOT Strategies

\begin{tabular}{|c|c|c|}
\hline No. & SWOT Matrix Strategy & Strategy Type \\
\hline \multicolumn{3}{|c|}{ S-O Strategy } \\
\hline 1 & $\begin{array}{l}\text { Increasing public trust } \\
\text { service to consumers } \\
\text { PT Pos Indonesia with a maximum } \\
\text { (S5-S12-S13-S14-S15-S17-S18-S19-O6) }\end{array}$ & Intensive Strategy \\
\hline 2 & $\begin{array}{l}\text { Optimize cooperation with } \\
\text { government (S1-S8-O8) }\end{array}$ & Intensive Strategy \\
\hline 3 & $\begin{array}{l}\text { Establish cooperation with the perpetrators } \\
\text { online business (S1-S23--03) }\end{array}$ & Intensive Strategy \\
\hline 4 & $\begin{array}{l}\text { Expanding the product shipping market } \\
\text { see growing market share (S1-S21-O4-07) }\end{array}$ & Intensive Strategy \\
\hline \multicolumn{3}{|c|}{ S-T Strategy } \\
\hline 1 & $\begin{array}{l}\text { Improving services and types product shipping goods } \\
\text { (S5-S14-S15-S17-S19-T1-T3) }\end{array}$ & Intensive Strategy \\
\hline 2 & $\begin{array}{l}\text { Offering product shipping services at a price } \\
\text { that can compete with competitors (S23-T1-T2-T3) }\end{array}$ & Intensive Strategy \\
\hline \multicolumn{3}{|c|}{ W-O Strategy } \\
\hline 1 & $\begin{array}{l}\text { Increase advertising / promotion by utilizing } \\
\text { information technology (W1-O1) }\end{array}$ & Intensive Strategy \\
\hline 2 & $\begin{array}{l}\text { Improve employee services } \\
\text { at the window (W3-W4-W5-06) }\end{array}$ & Intensive Strategy \\
\hline 3 & $\begin{array}{l}\text { Conduct training or training for employees } \\
\text { in accordance with the needs of his position and purpose } \\
\text { (W3-W4-W5-O6-O8) }\end{array}$ & Intensive Strategy \\
\hline \multicolumn{3}{|c|}{ W-T Strategy } \\
\hline 1 & $\begin{array}{l}\text { Optimizing human resources efficiently } \\
\text { (W2-T1-T3) }\end{array}$ & Defensif Strategy \\
\hline 2 & Increase the number of Padang branch offices (W1-T1) & Integration Strategy \\
\hline 3 & $\begin{array}{l}\text { To socialize to the public } \\
\text { about PT Pos Indonesia (W1-T2) }\end{array}$ & Intensive Strategy \\
\hline
\end{tabular}

3.) Major Strategy Matrix

The Major Strategy Matrix has two evaluative dimensions, namely competitive position and (industrial) market growth. Based on the CPM matrix assessment in Table 3 shows that the position of PT Pos Indonesia Padang is in a weak competitive position with 
a total value of 3.060 when compared to its competitors namely JNE and TIKI with values of 3.277 and 3.152, respectively. Whereas for the growth of the shipping or shipping industry, PT Pos Indonesia Padang is in a position of rapid market growth.

\begin{tabular}{|c|c|c|c|}
\hline & $\overline{\text { RAPID M }}$ & & \\
\hline & KUADRAN II & KUADRAN I & \\
\hline & $\begin{array}{l}\text { PT Pos Indonesia } \\
\text { Padang }\end{array}$ & & \\
\hline WEAK COMPETITIVE POSITION & & & STRONG COMPETITIVE POSITION \\
\hline & KUADRAN III & KUADRAN IV & \\
\hline & SLOW MA & & \\
\hline
\end{tabular}

Figure 3. Major Strategy Matrix

Matrix in Figure 3 shows that PT Pos Indonesia Padang is in quadrant II. Alternative strategies that can be carried out in quadrant II position are penetration strategies, integration strategies, and defensive strategies. The penetration strategy consists of market development strategies, market penetration, and product development. Whereas the integration strategy is carried out with horizontal integration. Furthermore, the defensive strategy is carried out by divestment and liquidation.

c. The Decision Stage

The final stage in the formulation of strategy is the decision stage. Strategic alternatives that have been obtained at the decision stage are analyzed to choose the best strategy proposed using the Quantitative Strategic Planning Matrix (QSPM). The alternatives proposed from each matrix at the matching stage are listed in Table 6. 
Andalas Management Review, Vol. 3 No. 2, 2019

Table 6

Alternative Strategies from the Matching Phase

\begin{tabular}{cl}
\hline MATRIX TYPE & RECOMMENDATION STRATEGY \\
\hline Internal External Matrix & Integration Strategy \\
& Intensif Strategy \\
SWOT Matrix & Intensif Strategy \\
& Integration Strategy \\
& Defensif Strategy \\
Big Strategy Matrix & Intensif Strategy \\
& Integration Strategy \\
& Defensif Strategy \\
\hline
\end{tabular}

Table 6 shows that the three matrices that have been designed at the matching stage there are three proposals namely integration strategy, intensive strategy, and defensive strategy. Integrative growth strategies consist of forward, backward and horizontal integration. While the intensive strategy consists of market penetration strategies, market development strategies, and product development strategies. Furthermore, the defensive strategy consists of a divestment and liquidation strategy. These three alternative strategies are then compared using the QSP matrix to determine which the best strategy is.

Table 7

QSPM

\begin{tabular}{|c|c|c|c|c|c|c|c|}
\hline \multirow[t]{4}{*}{ SWOT Factors } & \multirow{4}{*}{$\begin{array}{l}\text { Weig } \\
\text { ht }\end{array}$} & \multicolumn{6}{|c|}{ Final Result } \\
\hline & & \multirow{2}{*}{\multicolumn{2}{|c|}{$\begin{array}{l}\text { Strategy } \\
\text { Inten } \\
\text { sif }\end{array}$}} & \multirow{2}{*}{\multicolumn{2}{|c|}{$\begin{array}{c}\text { Strategy } \\
\text { Integration }\end{array}$}} & \multirow{2}{*}{\multicolumn{2}{|c|}{$\begin{array}{l}\text { Strategy } \\
\text { Defensif }\end{array}$}} \\
\hline & & & & & & & \\
\hline & & AS & TAS & AS & TAS & AS & TAS \\
\hline \multicolumn{8}{|l|}{ Opportunity (Peluang) } \\
\hline $\begin{array}{l}\text { Availability of information technology for } \\
\text { customers (website) }\end{array}$ & 0,102 & 3,750 & 0,381 & $\begin{array}{c}2,75 \\
0\end{array}$ & 0,280 & $\begin{array}{c}1,50 \\
0\end{array}$ & 0,153 \\
\hline $\begin{array}{l}\text { The rate of economic growth of the people of } \\
\text { the city of Padang }\end{array}$ & 0,096 & 3,500 & 0,336 & $\begin{array}{c}2,25 \\
0\end{array}$ & 0,216 & $\begin{array}{c}2,50 \\
0\end{array}$ & 0,240 \\
\hline Online business growth rates in Indonesia & 0,085 & 4,000 & 0,339 & $\begin{array}{c}3,75 \\
0\end{array}$ & 0,318 & $\begin{array}{c}2,75 \\
0\end{array}$ & 0,233 \\
\hline $\begin{array}{l}\text { Community culture towards the use of } \\
\text { courier services }\end{array}$ & 0,079 & 3,500 & 0,277 & $\begin{array}{c}2,75 \\
0\end{array}$ & 0,218 & $\begin{array}{c}3,25 \\
0\end{array}$ & 0,257 \\
\hline $\begin{array}{l}\text { The level of education of the people of the city } \\
\text { of Padang }\end{array}$ & 0,056 & 3,000 & 0,169 & $\begin{array}{c}2,00 \\
0\end{array}$ & 0,113 & $\begin{array}{c}1,75 \\
0\end{array}$ & 0,099 \\
\hline
\end{tabular}




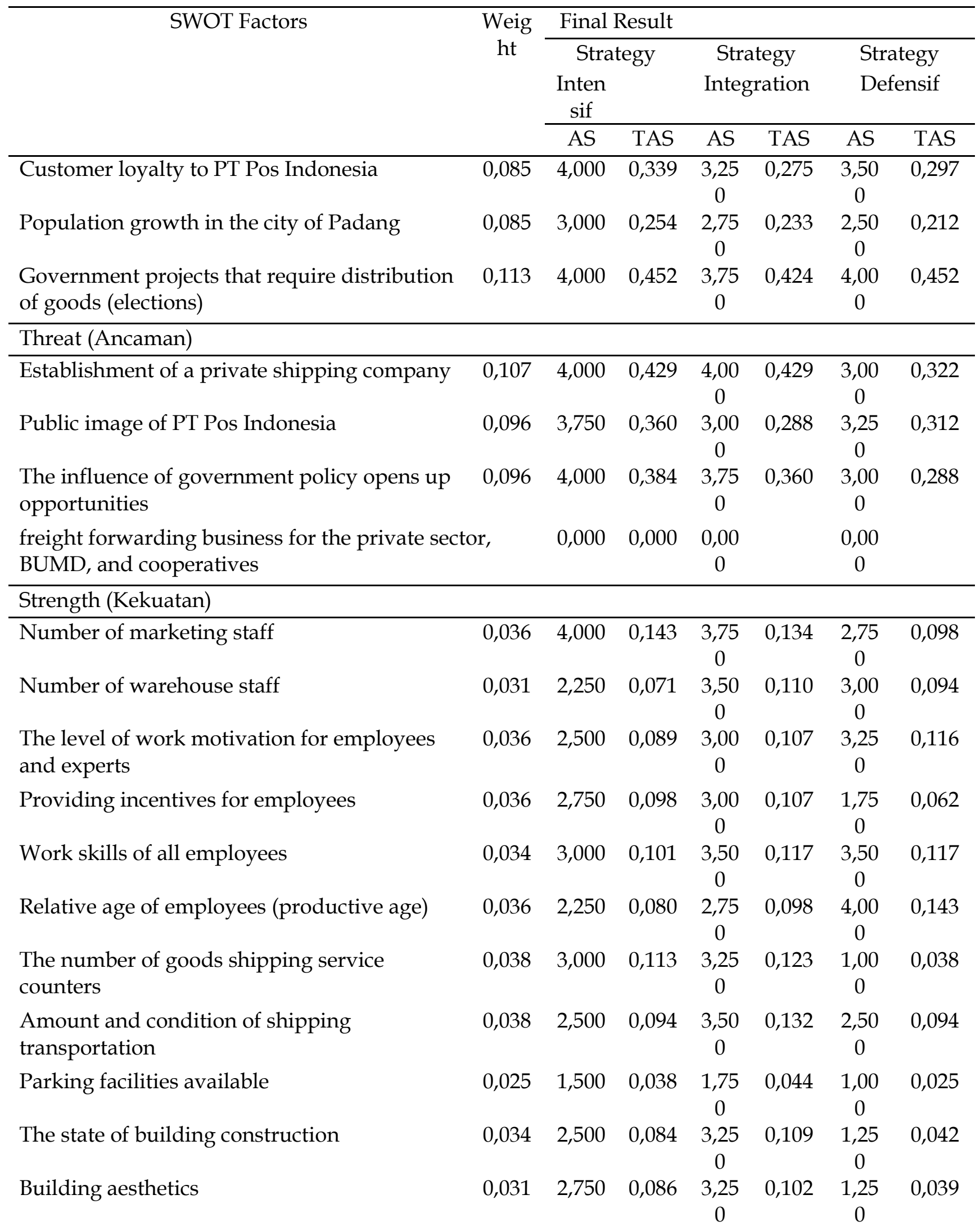




\begin{tabular}{|c|c|c|c|c|c|c|c|}
\hline \multirow[t]{3}{*}{ SWOT Factors } & \multirow{3}{*}{$\begin{array}{l}\text { Weig } \\
\text { ht }\end{array}$} & \multicolumn{6}{|c|}{ Final Result } \\
\hline & & \multicolumn{2}{|c|}{$\begin{array}{l}\text { Strategy } \\
\text { Inten } \\
\text { sif }\end{array}$} & \multicolumn{2}{|c|}{$\begin{array}{l}\text { Strategy } \\
\text { Integration }\end{array}$} & \multicolumn{2}{|c|}{$\begin{array}{l}\text { Strategy } \\
\text { Defensif }\end{array}$} \\
\hline & & AS & TAS & AS & TAS & AS & TAS \\
\hline $\begin{array}{l}\text { Skill of employee service at counters to } \\
\text { consumers }\end{array}$ & 0,042 & 3,000 & 0,126 & $\begin{array}{c}3,50 \\
0\end{array}$ & 0,147 & $\begin{array}{c}3,50 \\
0\end{array}$ & 0,147 \\
\hline $\begin{array}{l}\text { Skill of employee service to consumer } \\
\text { complaints }\end{array}$ & 0,042 & 3,000 & 0,126 & $\begin{array}{c}3,25 \\
0\end{array}$ & 0,136 & $\begin{array}{c}3,00 \\
0\end{array}$ & 0,126 \\
\hline $\begin{array}{l}\text { Speed of response of employee services at } \\
\text { counters }\end{array}$ & 0,042 & 3,000 & 0,126 & $\begin{array}{c}3,50 \\
0\end{array}$ & 0,147 & $\begin{array}{c}3,25 \\
0\end{array}$ & 0,136 \\
\hline $\begin{array}{l}\text { Speed of response to customer service } \\
\text { complaints by consumers }\end{array}$ & 0,042 & 3,000 & 0,126 & $\begin{array}{c}3,50 \\
0\end{array}$ & 0,147 & $\begin{array}{c}3,25 \\
0\end{array}$ & 0,136 \\
\hline Able to track the position of goods & 0,042 & 3,500 & 0,147 & $\begin{array}{c}3,50 \\
0\end{array}$ & 0,147 & $\begin{array}{c}1,25 \\
0\end{array}$ & 0,052 \\
\hline $\begin{array}{l}\text { Availability of guaranteed replacement of lost } \\
\text { items }\end{array}$ & 0,042 & 3,500 & 0,147 & $\begin{array}{c}3,50 \\
0\end{array}$ & 0,147 & $\begin{array}{c}2,00 \\
0\end{array}$ & 0,084 \\
\hline Friendliness of security services & 0,040 & 3,000 & 0,119 & $\begin{array}{c}2,50 \\
0\end{array}$ & 0,100 & $\begin{array}{c}3,00 \\
0\end{array}$ & 0,119 \\
\hline Ease of filing complaints by consumers & 0,042 & 3,000 & 0,126 & $\begin{array}{c}3,25 \\
0\end{array}$ & 0,136 & $\begin{array}{c}2,75 \\
0\end{array}$ & 0,115 \\
\hline Ease of information services & 0,040 & 3,250 & 0,129 & $\begin{array}{c}3,00 \\
0\end{array}$ & 0,119 & $\begin{array}{c}2,75 \\
0\end{array}$ & 0,110 \\
\hline $\begin{array}{l}\text { The affordability of the location of PT Pos } \\
\text { Indonesia by consumers }\end{array}$ & 0,038 & 3,750 & 0,142 & $\begin{array}{c}4,00 \\
0\end{array}$ & 0,151 & $\begin{array}{c}1,25 \\
0\end{array}$ & 0,047 \\
\hline Security of PT Pos Indonesia & 0,038 & 2,750 & 0,104 & $\begin{array}{c}2,50 \\
0\end{array}$ & 0,094 & $\begin{array}{c}1,00 \\
0\end{array}$ & 0,038 \\
\hline Goods shipping costs & 0,040 & 4,000 & 0,159 & $\begin{array}{c}3,75 \\
0\end{array}$ & 0,149 & $\begin{array}{c}2,00 \\
0\end{array}$ & 0,080 \\
\hline \multicolumn{8}{|l|}{ Weakness (Kelemahan) } \\
\hline Promotion / advertisement level & 0,029 & 4,000 & 0,117 & $\begin{array}{c}4,00 \\
0\end{array}$ & 0,117 & $\begin{array}{c}2,00 \\
0\end{array}$ & 0,059 \\
\hline Number of senders (couriers) & 0,025 & 3,500 & 0,088 & $\begin{array}{c}3,75 \\
0\end{array}$ & 0,094 & $\begin{array}{c}3,25 \\
0\end{array}$ & 0,082 \\
\hline Skill of security services & 0,023 & 2,000 & 0,046 & $\begin{array}{c}1,50 \\
0\end{array}$ & 0,035 & $\begin{array}{c}2,50 \\
0\end{array}$ & 0,058 \\
\hline Information service skills by employees & 0,029 & 2,750 & 0,081 & $\begin{array}{c}3,00 \\
0\end{array}$ & 0,088 & $\begin{array}{c}2,50 \\
0\end{array}$ & 0,073 \\
\hline $\begin{array}{l}\text { Friendliness of employee services at the ticket } \\
\text { window }\end{array}$ & 0,031 & 3,000 & 0,094 & $\begin{array}{c}3,50 \\
0\end{array}$ & 0,110 & $\begin{array}{c}2,75 \\
0\end{array}$ & 0,086 \\
\hline TOTAL & & & 6,721 & & 6,401 & & 5,282 \\
\hline
\end{tabular}


Based on the QSPM, it can be concluded that the best strategy to be carried out by PT Pos Indonesia Padang is an intensive strategy. The intensive strategy requires intensive efforts to increase company competition through existing products. The proposed strategy was given to PT Pos Indonesia Padang through the validation stage with the Marketing Manager of PT Pos Indonesia Padang. Validation is carried out to match the strategy of this company with the condition and capability of PT Pos Indonesia Padang. Table 8 shows the comparison between the initial strategy and the proposed strategy based on the chosen strategy. The initial strategy is a strategy that has been implemented by PT Pos Indonesia Padang. Information on this initial strategy was obtained from the Marketing Manager of PT Pos Indonesia Padang.

Table 8

Prefix and Proposed Strategy of PT Pos Indonesia Padang

\begin{tabular}{lll}
\hline Comparison & \multicolumn{1}{c}{ Initial Strategy } & \multicolumn{1}{c}{ Proposed Strategy } \\
\hline Market penetration & $\begin{array}{l}\text { Marketing through advertising } \\
\text { in print media (Newspapers). }\end{array}$ & $\begin{array}{l}\text { 1. Improving the quality of } \\
\text { services provided to agencies that } \\
\text { have collaborated with PT Pos } \\
\text { Indonesia. }\end{array}$ \\
Market Development & $\begin{array}{l}\text { Cooperation with government } \\
\text { agencies in the distribution of } \\
\text { goods, such as: }\end{array}$ & $\begin{array}{l}\text { 1. Cooperation with online } \\
\text { businesses and small and medium } \\
\text { businesses in the city of Padang } \\
\text { by marketing products in the Pos } \\
\text { gallery. }\end{array}$ \\
& $\begin{array}{l}\text { 2. Cultivation of industrial estates } \\
\text { in the city of Padang. }\end{array}$ \\
& $\begin{array}{l}\text { 3. Cultivation of the tourist } \\
\text { 2. Education Office (SBMPTN). }\end{array}$ \\
3. Ministry of Religion (hajj cargo). & \\
4. BPJS. &
\end{tabular}




\begin{tabular}{lll}
\hline \multicolumn{1}{c}{ Comparison } & \multicolumn{1}{c}{ Initial Strategy } & \multicolumn{1}{c}{ Proposed Strategy } \\
\hline Product & EMS service (overseas & Provides export services \\
Development & shipping). & specifically for SME products. \\
& & This strategy is carried out by \\
& collaborating with home industry \\
& entrepreneurs and the cooperative \\
& and industrial offices.
\end{tabular}

\section{d. CONCLUSION AND IMPLICATIONS}

The position of PT Pos Indonesia Padang based on the Internal External matrix is in quadrant I, where the position shows that the internal condition is strong and the external is high. This shows that PT Pos Indonesia Padang is able to compete with its business environment. Whereas based on the Major Strategy matrix, PT Pos Indonesia Padang is in quadrant II where the quadrant shows that the rapid market growth of the industrial shipping market and weak competitive position. The development strategy that must be carried out by PT Pos Indonesia Padang is an intensive strategy consisting of market penetration, market development, and product development. Market penetration is carried out by continuing to collaborate with agencies that have already cooperated with PT Pos Indonesia Padang. Maintaining cooperation with these agencies is carried out by maintaining and improving PT Pos Indonesia Padang's shipping services so that these agencies are satisfied with the services provided. In addition, the market penetration strategy undertaken is to carry out promotions through the website. The proposed strategy for developing PT Pos Indonesia's market is to collaborate with online businesses and small and medium businesses in the city of Padang. In addition the strategy that can be done is the cultivation of industrial and tourist areas in the city of Padang. The proposed strategy for developing PT Pos Indonesia Padang products is to provide export services specifically for SME products. Some things that need attention and refinement in further research are: Periodic performance assessments are needed to evaluate the achievement of the strategic plan. In the formulation of the next strategy it is necessary to evaluate the achievement of the strategy that was previously used to be input for planning the next strategy. 
Andalas Management Review, Vol. 3 No. 2, 2019

\section{REFERENCES}

Amaly, I. (2013), "Perencanaan Strategi Pengembangan Semen Padang Hospital", Universitas Andalas.

David, F. R. (2009), Strategic Management: Manajemen Strategis Konsep, Salemba Empat, Jakarta.

Direktorat Jenderal Perdagangan Dalam Negeri (2012), "Bisnis Online Berkembang", Jasa Ekspedisi Tertantang.

Doni, F. R. and Faqih, H. (2017), "Perilaku Penggunaan Media Sosial Pada Kalangan Remaja", IJSE-Indonesian Journal on Software Engineering.

Edisi, M. M. (2014), "Event Veritrans: Rise of E-Commerce", 08/XIV, August.

Lukito, V. T., Lianto, B. and Surjani, R. M. (2013), "Perancangan strategi bisnis di PT. Coronet Crown", Calyptra, Vol.2, No.1, pp.1-19.

Madni, G. R. (2014), "Consumer's Behavior and Effectiveness of Social Media", Global Journal of Management And Business Research.

Papagiannidis, S. et al. (2017), "Preferences of Smart Shopping Channels and Their Impact on Perceived Wellbeing and Social Inclusion", Computers in Human Behavior, doi: 10.1016/j.chb.2017.04.029.

Rozelin, D. (2008), "Perencanaan Strategi Perusahaan Daerah Air Minum Kota Padang Tahun 2007 - 2008", Universitas Andalas.

Saxena, R. P. (2019), "Online Shopping Behavior in West and East: A Comparative Analysis of USA and UAE Shoppers", Academy of Marketing Studies Journal.

Schmid, B. and Axhausen, K. W. (2017), "In-store vs. Online Shopping of Search and Experience Goods: A Hybrid Choice Approach In-store vs. Online Shopping of Search and Experience goods: A Hybrid Choice Approach", Journal of Choice Modelling. doi: 10.1016/j.jocm.2018.03.001.

Sinaga, B. B. (2012), "Evaluasi Kinerja PT Pos Indonesia Padang dengan Menggunakan Pendekatan Lean Logistics", Universitas Andalas.

Wamuyu, P. K. (2015), 'The Impact of Information and Communication Technology Adoption and Diffusion on Technology Entrepreneurship in Developing Countries: The Case of Kenya", Information Technology for Development, doi: 10.1080/02681102.2014.948372. 